\title{
MODEL VÝVOJE VALEČOVSKÉ SÍDELNÍ AGLOMERACE
}

\author{
FRANTIŠEK GABRIEL
}

\begin{abstract}
Abstrakt: Sídelní aglomerace Valečov, nazvaná podle hradu, obsahujícího jádro a predhradi, zahrnuje dalši dvě sidelni jednotky. Přilehlou sidelní jednotku vymezuje opevněni, navazující na výše položený hrad, a samostatná sídelní jednotka, kterou, ač leži v bezprostředni blizkosti hradu, obepíná vlastni uzavřené opevnèní. Aglomerace nás staví před řadu otázek souvisejicich s dobou vzniku sídelních jednotek, s jejich funkcemi, majetkovými poměry a změnami aglomerace.
\end{abstract}

Klíčová slova: aglomerace - sídelní jednotka - datace - stavební vývoj.

\section{Development Model of the Settlement Agglomeration in Valečov}

Abstract: The settlement agglomeration in Valečov, which got its name after a castle comprising a core and a bailey, includes another two settlement units. The adjacent settlement unit is delimited by a fortification adjoining the higher-situated castle, and by an independent settlement unit that, though located in close proximity of the castle, is encircled by its own closed fortification. The agglomeration poses a number of questions connected with the period of the origin of settlement units, their functions, property conditions and agglomeration changes.

Key words: agglomeration - settlement unit - dating - building development.

Do nepřeberného množství zajímavostí Českého ráje řadíme i lokalitu Valečov (k. ú. Boseň, okr. Mladá Boleslav), pojmenovanou podle hradu, tvořenou však trojicí sídelních jednotek. Celá aglomerace se rozkládá na ploše ca $36187 \mathrm{~m}^{2}$. Sestává z hradu o rozloze přibližně $6521 \mathrm{~m}^{2}$, tvořeného jádrem a předhradím, dále z prrilehlé sídelní jednotky, jejíž plochu o ca $8936 \mathrm{~m}^{2}$ vymezuje opevnění, navazující na výše položený hrad, a ze samostatné sídelní jednotky, zabírající zbylých přibližně $20730 \mathrm{~m}^{2}$, kterou, ač leží v bezprostřední blízkosti hradu, obepíná vlastní uzavřené opevnění.

Opomineme-li strohé historiografické zápisy o hradě, započaté již v období baroka (Šimák 1930, 594), věnoval se prvně informacím ze zapsaných dobových zpráv o hradě a pravděpodobně i o dalších dvou sídelních jednotkách aglomerace A. Sedláček (první vydání 1895, citováno z třetího vydání 1997, 111-122). Na základě těchto informací vypracoval a rozvedl velmi podrobný model majetkových poměrů J. V. Šimák (1917, 213-287) a po více než sedmdesáti letech stručně shrnul P. Chotěbor (1986, 184-186), který se při datování opřel i o hmotné prameny. Posledně se minulosti aglomerace, především však její třetí části, samostatné sídelní jednotky, dotkli K. Podroužek-F. Gabriel (2007, 211-224). Ostatní odborné práce (např. Menclová 1972, 339341; Durdík 1999, 580-581) se historii hradu věnují minimálně, nebo vůbec ne (např. GabrielPeřina-Podroužek v tisku). Poznámky o movitých nálezech z hradu uvádějí J. Filip $(1947,153)$ a P. Chotěbor (1986, 184-186). O keramice se zmiňují J. Waldhauser-P. Sosnovec (2004, 385-386).

Aglomerace vznikla na protáhlé pískovcové pseudoostrožně, orientované v ose od šíje k opyši ve směru jihovýchod-severozápad (obr. 1). Nad její půdní kryt vystupují vypreparované pískovcové bloky (Gabriel-Panáček-Podroužek 2011, 15, 136) řazené u opyše do tří skalních suků uspořádaných kolmo k ose pseudoostrožny, které dosahují až do výšky $30 \mathrm{~m}$. Tyto suky, upravené lámáním a sekáním, využil stavebník jako staveniště hradu Valečova. Oba krajní, přední i zadní, se staly součástí opevnění hradu, zatímco střední suk, který převyšuje niveletu terénního tvaru, posloužil jako podnož paláce.

Zbylá část pseudoostrožny posloužila k založení samostatné sídelní jednotky, kterou na severní straně odděluje od hradu jeho opevnění a příkop, po severovýchodní, západní, jihozápadní a jižní straně ji chrání hrana pseudoostrožny a na jihovýchodní straně šíjový příkop.

Sídelní jednotka přilehlá k hradu využila spočinek prodlužující opyš k severozápadu a pokračující pod západní stranou hradu. Ze severozápadu a z jihu stoupají na spočinek dvě komuni- 


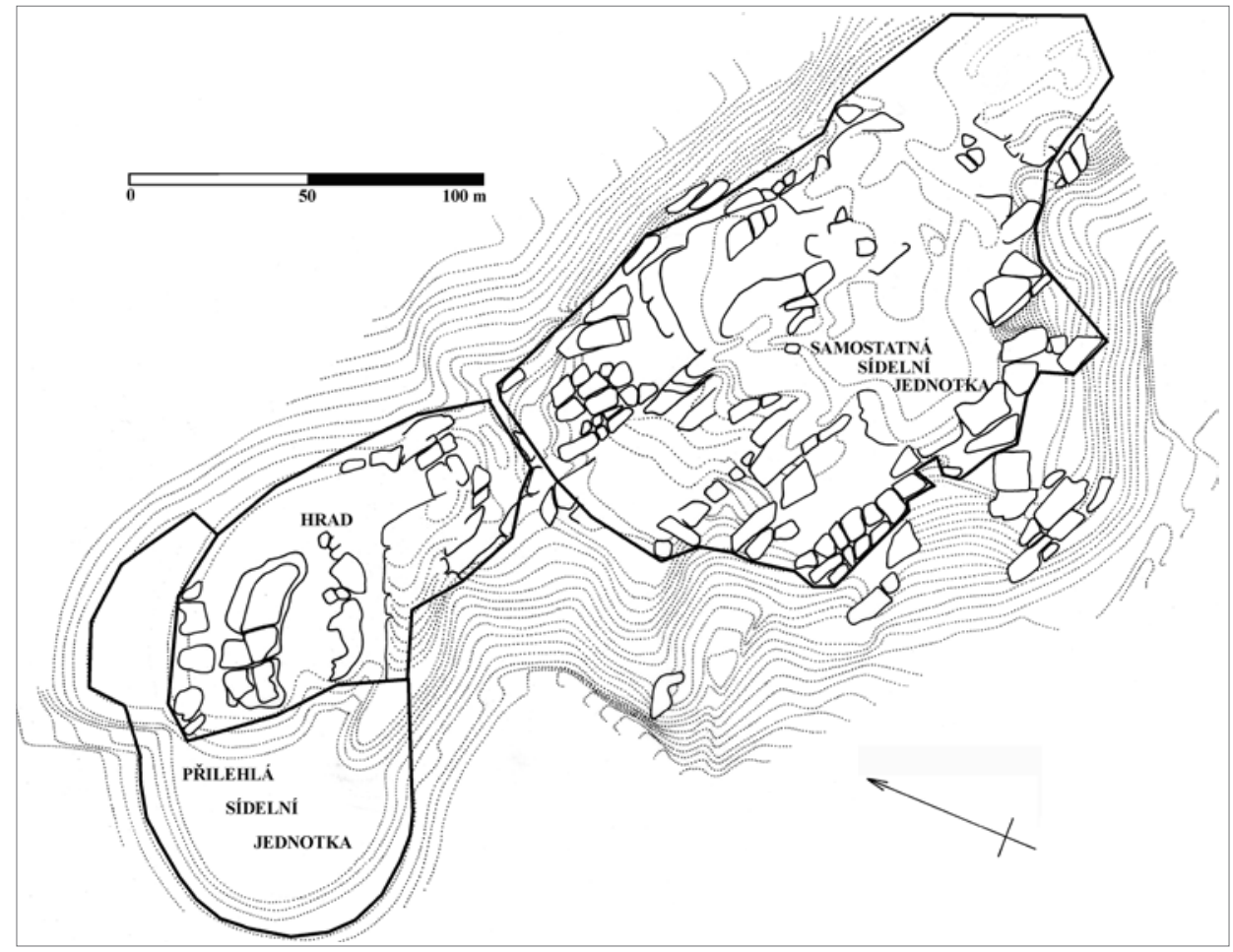

Obr. 1. Valečovská aglomerace. Zaměření P. Chotěbor (1986, obr. 1; hrad a přilehlá sídelní jednotka) a F. Gabriel, L. Kursová, I. Peřina (samostatná sídelní jednotka). Základní rozdělení sídelních jednotek. 1 - hranice sídelních jednotek aglomerace, doložené stopami, valy a výraznými terénními zlomy, 2 - odhadované hranice sídelních jednotek aglomerace. Úprava autor, kresba B. Linhartová.

Abb. 1. Ballungsraum Valečov. Vermessung P. Chotěbor (1986, Abb. 1; Burg und angrenzende Siedlungseinheit), und F. Gabriel, L. Kursová, I. Peřina (selbständige Siedlungseinheit). Grundaufteilung der Siedlungseinheiten. 1 - durch Spuren, Wälle und markante Geländebrüche belegte Grenze der Siedlungseinheiten des Ballungsraums, 2 - geschätzte Grenze der Siedlungseinheiten des Ballungsraumes. Bearbeitung vom Verfasser, Zeichnung B. Linhartová.

kace. První vystupuje po západním úbočí, druhá vybíhá ze severozápadního úbočí pod opyšem. Její soudobá úprava dělí spočinek na dvě části.

Zjevně členitá lokalita Valečov nás staví před řadu otázek souvisejících s dobou vzniku sídelních jednotek, s jejich funkcemi, majetkovými poměry a změnami aglomerace. Vycházíme z modelu, který za nejstarší sídelní jednotku považuje hrad.

O existenci hradu nás prvně informuje predikát „Bartoss iuuenis de waleczowa et de strak“ z roku 1323 (RTV, 72 č. 378). První dobový zápis zaznamenávající jméno hradu ovšem neuvádí dobu jeho vzniku, ale pouze dobu existence sídla. Otázku po časovém rozdílu mezi založením hradu a zlistiněním jeho jména by mohly zodpovědět keramické fragmenty, získané povětšinou povrchovými sběry nebo sběry z výkopků. P. Chotěbor (1986, 186-193), který významnou část nálezů ve své práci shromáždil, je datuje převážně do závěru 14. a následujících století, ojediněle do přelomu 13. a 14. století. Těchto osm zdánlivě nejstarších keramických zlomků nádob, z nichž tři zdobí rádýlko a jeden rytá vlnice (Chotěbor 1986, 191), však starší založení hradu jednoznačně nedokládají, nebot' využití stř̌edověké keramiky pro absolutní datování lokalit v Pojizeří bylo v poslední době zpochybněno (Gabriel-Peřina, I. 2009; Klápště 2013, 360-361), a nelze tedy vyloučit ani nezbytnost revize nejstaršího osídlení Valečova, nemluvě o četnostně nevýrazném množství oněch osmi fragmentů. Zdá se, že současný stav našich znalostí o pojizerské keramice a keramické nálezy z hradu nedovolují jeho počátky výrazněji posunout před rok první zmínky. 
Jednoznačné nejsou ani vztahy členů rodu pyšnícího se predikátem ,z Valečova“ a erbem s tváří zlatého hořícího slunce na modrém štítě. Nevíme, jaký byl vztah mladšího a staršího Bartoše z roku 1323 (RTV, 72 č. 378) ke Zdeňkovi z Valečova (Sedláček 1997, 116). ${ }^{1}$ Za Zdeňkovy syny uvádí J. V. Šimák $(1917,114)$ bratry „Woyslai plebani in Bosna, Benessij, Stiborij et Herssonis clientum de Walessczow", jmenované při podávání do kaple sv. Hypolita pod Vyšehradem v dubnu roku 1362 (LC I/1, 174). Již na konci téhož roku, v prosinci, mizí z patronů kaple Beneš (LC I/1, 191) a v roce 1393 je jako zakladatel kaplanství v Bosni jmenován pouze „Hersso miles de Waleczow" s manželkou Bětou (LE IV, 395, č. 549). Následně se ve Valečově uvázali bratři Bartoš a Bernart, které J. V. Šimák $(1917,116)$ označuje, soudě z pojmenování Bartoše při svěcení v roce 1399 „Bartoš Heršůuv", za syny Herše. P. Chotěbor $(1986,184)$, který tento vztah přijímá, uvádí v roce 1399 svěcení Bartoše na kněze, ve skutečnosti však šlo o vysvěcení na akolyta, takže zůstával laikem. Oba bratři uplatnili v letech 1412 a 1413 podací právo na faráře v Bosni (LC VII, 40, 75).

V období husitských válek se Bartoš a Bernart přiklonili k podobojím a svojí aktivitou u bratrstva Orebského dosáhli významného postavení, které dokládá zvací list Jana Žižky z Kalichu na poradu do Německého Brodu, zaslaný 26. 3. 1423 (Podroužek-Gabriel 2007, 213, 222). Bernart usedl v roce 1422 mezi řešitele sporu Staroměstských a Novoměstských Pražanů (AČ I, 209 č. 21). Rovněž podporovali Jana Žižku na tažení do severních Čech (Sedláček 1997, 118). Důležité je upozornění na skutečnost, že od roku 1423 začala být v písemných pramenech vynechávána křestní jména bratř́i a bylo užíváno pouze označení „Valečovský“, z čehož Sedláček dovozuje smrt jednoho $\mathrm{z}$ bratrů. ${ }^{2}$

V roce 1439 přerušil rodovou držbu Valečova Jindřich z Vartenberku, když hrad zradou dobyl a vdovu Machnu ${ }^{3}$ se dvěma syny odvedl na „hrad Děčín a Valečov úplně vypálil““(StL, 137). Pro své osvobození postoupila Machna v roce 1441 Valečov svému vězniteli (StL, 146). Do rodové držby se vrátil někdy mezi roky 1441 a 1452, kdy na něm již seděl Jan z Valečova (AČ XV, 210 č. 101). Jaký byl vztah vdovy Machny k Janovi z Valečova, Břeňkovi a Vaňkovi, držícím následně Valečov, prameny neuvádí. Označení Vaňka a Břeňka za její syny uvádí J. V. Šimák $(1917,266)$ užitím slovesa „tuším“ jako hypotézu, kterou však P. Chotěbor $(1986,184)$ považuje za fakt. Zůstává tak otázkou, zda byl Jan jedním ze dvou synů odvedených s Machnou na Děčín, a tedy i bratrem Břeňka, nebo zda byl jeho vzdálenějším příbuzným, zatímco Břeňkovým bratrem a synem Machny byl Vaněk. Rovněž zůstává otázkou, proč A. Sedláček (1997, 118) uvažuje pouze o těchto dvou možnostech, a nikoliv o možnosti, že Jan byl bratrem Vaňka a vzdálenějším př́ibuzným byl Břeněk, nebo že všichni tři jmenovaní byli bratry, což by nejlépe odpovídalo následujícímu modelu majetkové držby. ${ }^{4}$ At' již byly rodinné vztahy mezi zúčastněnými jakékoliv, setrval Valečov v držbě rodu až do jeho vymření po meči, které můžeme vložit mezi roky 1474 a $1481 .{ }^{5}$ Mezi těmito roky získal valečovské zboží postavou Samuela z Hrádku jiný, ač nejspíše s Valečovskými sňatkem spř́izněný rod.

\footnotetext{
1 Prameny jej nazývají „Zdeslaum de Juchosirb et de Zabirdowicz“ (RTT I, 65 č. 204). J. V. Šimák (1917, 113) jej hypoteticky spojuje s jedním z Bartošů a P. Chotěbor (1986, 184) předpokládá, že byl bratrem Bartoše staršího (RTV, 72 č. 378).

2 To však nelze jednoznačně přiřadit do doby kolem roku 1423, nebot' následně A. Sedláček $(1997,118)$ upozorňuje, ,že ,Valečovšti ' ještě roku 1431 drželi s jednotou a vojskem Sirotčim". Autorův pramen se však bohužel nepodařilo prověřit, takže není jisté, zda je v dobovém textu skutečně užit plurál.

3 Pramen neuvádí ani při jedné zprávě (StL, 137, 146), kterého z bratrů byla Machna chotí.

4 A. Sedláček $(1997,118)$ předpokládá, že Valečov po roce 1452 drželi tři členové rodu Valečovských. Jan z Valečova, připomínaný prvně roku 1433 (pramen uveden pouze: Archiv zem. Morav.) a následně roku 1441 (RTT II, 193), držel od roku 1462 zboži Lhotice (RTT II, 326), kde o dva roky později umřel bez dědiců. O druhém držiteli Valečova Břeňkovi A. Sedláček $(1997,118)$ pouze sděluje, že záhy zemřel. Poslední, Vaněk z Valečova, se stal zemským podkomořím a v této funkci setrval až do roku 1467. Zemřel 19. února roku 1472 (StL, 223). Ačkoliv všichni tři členové rodu stáli roku 1448 s Jiřím Poděbradským před Prahou (Sedláček 1997, 118), jejich rodové vztahy neznáme. Jisté pouze je, že Jan měl ,fratres patrueles“ Václava, se kterým v roce 1441 prodával rodový majetek (RTT II, 193). Jak J. V. Šimák (1917, 267) dospěl ke ztotožnění Václava s Vaňkem, neuvádí. Zcela nesmyslná je jeho hypotéza o Machně jako manželce Jana.

5 Posledním mužským př́slušníkem rodu Valečovských byl Viktoryn (Chotěbor 1986, 185), jehož poručníkem byl Samuel z Hrádku (AČ IV, 280 č. 31, 281-282 č. 35). Viktoryn byl dle A. Sedláčka $(1997,118)$ i P. Chotěbora $(1986,185)$ potomkem Vaňka z Valečova, jak rovněž uvádí i zápis z roku 1474 (AČ IV, 280 č. 31), a bratrem pěti starších sester (Sedláček 1994, 225). Kdy Viktoryn skonal, prameny neuvádí. A. Sedláček (1997, 118-119) předpokládá, že někdy mezi rokem 1474, kdy se svým poručníkem a možná i strýcem Samuelem z Hrádku vede spor proti Haškovi Sřižkovi (AČ IV, 280 č. 31, 281-282 č. 35), a rokem 1481, kdy se Samuel z Hrádku ujal všech jeho statků a následně začal uživat i predikát „z Valečova“. Podobně dospěl k datování smrti Viktoryna J. V. Šimák $(1917,272)$.
} 
Četné rody, které se na Valečově od sklonku 15. století až do Bílé hory střídaly, někdy v rychlém, jindy v pomalém sledu, byly, zdá se, v převážné většině reformně orientované a tolerantní k víře poddaných (Podroužek-Gabriel 2007, 215-220). Změna nepochybně nastala po Bílé hoře, kdy byl valečovský majetek Kryštofa Kapouna ze Svojkova v roce 1622 zkonfiskován. Dle názoru P. Chotěbora $(1986,185)$ již hrad nebyl centrem panství a šlechta na něm většinou nebydlela. Podobný model dějin Valečova nastínil i T. Durdík $(1999,580)$. D. Menclová $(1972$, 341) předpokládá, že hrad byl užíván až do roku 1652, kdy jej Daniel Freisleben připojil k panství mnichovohradišt'skému. Autorka se však mýlí, nebot’ Daniel Freisleben z Buschhofenu byl roku 1652 již mrtev a panství držel jeho syn Jan Vilém, který je v témže roce prodal Ferdinandu Arnoštovi z Valdštejna. Valdštejn, po dokoupení zbytku panství od Albrechta Kapouna ze Svojkova, celé zboží připojil k panství zvířetickému (Sedláček 1997, 122). Autor předpokládá, že hrad byl do sklonku 17. století ještě užíván úředníky panství. O něco déle prodloužil obývání hradu autor kapitoly o Valečově v knize Hrady, zámky a tvrze v Čechách, na Moravě a ve Slezsku, který uvádí Valečov jako sídlo „obročniho pro kněžmostskou část panstvi“". Správa panství však byla počátkem 18. století soustředěna $v$ Klášteře a hrad sloužil, ovšem pouze krátce, za obydlí úředníkům. Ještě v průběhu první poloviny 18. století byl zcela opuštěn a zpustl. Až do počátku 20. století zůstaly obývány pouze některé objekty v samostatné sídelní jednotce na východní straně pseudoostrožny (Kolektiv autorů 1984, 494). Kde autor kapitoly o Valečově čerpal své informace, uvedeno není, stejně jako nejsou uvedeny písemné prameny v ostatních kapitolách této knihy.

I přes omezený počet informací lze alespoň v hrubých rysech naznačit počátky valečovské aglomerace, změny v jejích majetkových poměrech a dobu postupného opouštění. Výrazně méně informací se dochovalo o funkci a postavení jejích sídelních jednotek. Jistý je pouze hrad, ačkoliv i u něho zůstává řada otázek nevyřešena.

Za východisko modelování funkce, postavení a zásahů do podoby valečovské aglomerace volíme dochované dobové zápisy, specifikující části jednotlivých sídelních jednotek. Z nich vynecháváme zmínky o hradě reprezentované druhovým jménem „hrad“, „,zámek“ či jejich cizojazyčnými synonymy a také uvedení vlastního jména Valečov, at' již užité jako pojmenování lokality, nebo jako predikát, případně příjmení šlechty. Na rozdíl od takových dokladů existence a od informací o majetkových vztazích známe dobových zápisů o funkci, postavení a zásahů do podoby valečovské aglomerace jen velmi málo.

První dosud známou informaci o složitější sídelní situaci na Valečově registruje historiografie na zvací listině Jana Žižky z Kalichu, pořízené 26. 3. 1423. Na rubu missivu je za salutací uvedeno: „Bartošěvi, Bernartovi z menšieho Tábora na Valečově bud’ dán“. K. PodroužekF. Gabriel $(2007,222)$ interpretují text jako inskripci. Přijmeme-li tuto interpretaci, pak nás informuje o existenci nějaké sídelní jednotky, jmenované „menši Tábor na Valečově. Prokazatelně se tato část inskripce nevztahovala $\mathrm{k}$ hradu, který by dostačovalo označit pouze vlastním jménem s případným doplněním o jméno druhové. S ohledem k uvedení „na Valečově“, které je asi chápáno jako označení celé aglomerace, zbývají pouze dvě sídelní jednotky, přilehlá a samostatná. Kterou z nich v inskripci autor mínil, nám ovšem neuvádí.

Nejstarší informace o zásahu do podoby hradu uvádí narativní pramen hlásící se k roku 1439. Sděluje nám, že hrad dobyl Jindřich z Vartenberku a „Valečov úplně vypálil“ (StL, 137). O interpretaci rodových vztahů, jak jsme již uvedli výše, se pokusil A. Sedláček (1997, 118), zatímco informace o vypálení Valečova se jemu a zřejmě i ostatním historikům jeví jako jednoznačná. Je však třeba upozornit, že pod označením Valečov nemusel kronikář vnímat výhradně hrad, ale mohl jej vztahovat i na další dvě zbylé sídelní jednotky, jak by naznačovalo slovní spojení „úplně vypálil“, nebo dokonce pouze na ně, zatímco hrad mohl zůstat zničení ušetřen, aby dál sloužil zástupci Jindřicha a jeho posádce, chránícím hrad před vypuzeným služebnictvem Machny a okolním obyvatelstvem, které by jinak jistě využilo př́iležitosti k vylepšení svého majetku. Navíc samo sdělení ,úplně vypálil“" mohlo mít za cíl vyvolat dojem, že sídlo, at’ jím již bylo cokoliv, zničil dobyvatel do základů, zatímco ve skutečnosti mohlo jít pouze o zásah menší, třeba i snadno opravitelný. $Z$ tohoto důvodu je třeba jen velmi opatrně zvažovat spojení 
zaznamenané události s datací změn stavby. Nelze ani vyloučit, že podobných dobyvatelských nebo jiných katastrof končících poškozením či zničením zástavby mohla minulost přinést podstatně více, a zůstává tedy otázkou, zda právě uvedený zápis vedl k přestavbě sídla, jak naznačují D. Menclová $(1972,340)$, P. Chotěbor $(1986,185)$ či T. Durdík $(1999,580)$.

Další zmínku o vypálení nějaké sídelní jednotky u Valečova přináší list, daný v Třeboni 14. 6. 1470, ve kterém se uvádí, ,že do Boleslavska byli vtrhli pan Jaroslav s Slezáky a vypálili Turnov a pod Valečovem městečko" (AČ VIII, 3-4 č. 379). A. Sedláček (1997, 118) za tuto informaci vkládá „,(Kněžmost?)“, podtrhuje tím nejistotu o prrípadné lokalizaci městečka pod Valečovem. Sedláčkova nejistota je oprávněná, nebot' Valečov je od Kněžmostu vzdálen téměř trri kilometry, a důvod jejich spojení do pojmu ,a pod Valečovem městečko“ se tak nejeví př́liš logický. Blíže pod hradem se nabízí jedna ze sídelních jednotek valečovské aglomerace, především samostatná sídelní jednotka, která, alespoň částečně, funkci městečka plnila.

S touto informací souvisí i upozornění P. Chotěbora $(1986,185)$ o zpustošení valečovského panství v roce 1468 křižáky z Lužice, s odvoláním na J. V. Šimáka $(1917,271)$. Otázkou zůstává, zda jde o dvě napadení valečovského panství, první v roce 1468 a druhé o dva roky později $\mathrm{v}$ roce 1470 , nebo zda se někteř́ starší autoři (Šimák 1917, 271) zmýlili. ${ }^{6}$

V letech 1555 a 1617 nabízí dělení valečovského panství popisy hradu zapsané v Deskách zemských a pravděpodobně v plném rozsahu včetně uvedení pramene publikované A. Sedláčkem (1997, 119-122). Starší, stručnější popis z 10. 6. 1555 uvádí společnou studnici a v přední polovici hradu předhradí (A na obr. 2; písmena v závorkách jsou shodná s písmeny na plánu ukazujícími na situování popisovaných částí hradu podle předkládaného modelu) ,až po dưm zadní (B) a starou světnici (C) v psinci (D) a tu vejda do zámku s pekárnou i stím domem nad vraty (E) s kuchyní, špižirnou, sklepy, s věži (F), též dolními sklepy vínu i pivu a světnicemi, kromě toho polovici dvoru hořejšiho, dvůr dolejní všechen, městečko celé Kněžmost, krčmu pod hradem rečenou Tábor" a v zadní polovici hradu ,zadni di̊m (B) až pod starou světničku (C) v psinci (D) is tou starou světničkou $(\mathrm{C})$, pokoj $(\mathrm{G})$ nad predními vraty $(\mathrm{H})$, půl dvoru hořejšího, ..." (DZ 56. B 27-C 23).

Druhý zápis ze 4. 7. 1617 nabízí podle A. Sedláčka $(1997,121)$ podrobný, avšak značně nepřehledný, a tím i nejednoznačný popis hradu. Začíná jeho zadní polovicí (B na obr. 3; písmena v závorkách jsou shodná s písmeny na plánu ukazujícími na situování popisovaných částí hradu podle předkládaného modelu) a pravděpodobně volně přechází do skalních bloků předního (starého) domu (E): „při zemi sín nevelkou pod prampouchem klenutým, z niž jest schod nahoru na siňku před dřevěnou světnici, z té sinkyy sklep při zemi klenutý, u něhož jsou železné dveře červenou barvou barvené, z toho sklepu druhý sklep a z toho opět sińku klenutou, z niž se na malý parkánek nebo plácek (A) za starým domem (E) vycházi a za tou sínkou svétnici klenutou".? Popis pokračuje horní částí předního (starého) domu (E), zbudovanou na skalních blocích, a asi opět volně přechází po pavlačích do zadního (nového) domu: „Nahoře nad tím stavením měl světnici dřevěnou a za ní komůrku a sklípek, z něhož se vycházelo druhými dveřmi ke schodu, po němž se $k$ světnici Veselici chodilo na pavlač, která byla nad kuchyní, před touž světnici síňku malou, z níž se šlo po schodech nahoru pod krov a vycházelo se na pavlač (J), která hleděla do placu velkého (K), světnici velikou, která sloula prostřední, síňku za touž světnicí, z niž se chodilo pres pavlač kamennou do pokojů nad branou dolejši $(\mathrm{H})$, za touž síni dvě komory z jedné do druhé a za těmi komorami světnici, kteráž sloula zadní, i s tím překlenutím, kudy se k té světnici přicházelo. Nad těmi pokoji obdržel podkrovi všecko, které ty pokoje napředpsané krylo, ale také na ně sám nakládati povinen byl. K tomuto dílu patřily také světnička nad branou dolejši (G), siňka a komůrka s dvěma sklipky pod tou komůrkou (jeden nad druhým), do kterýchž pokoju se chodilo z té sině za prostředni světnici do pavlače kamenné, malý plácek nebo parkánek(A) za starým domem a vněm sklipek nahoře ve skále vytesaný, do něhož se z téhož parkánku po

6 O stejném údaji pojednává i poznámka ke jménu ,pan Jaroslav“v Archivu českém (AČ VIII, 3-4 č. 379), odvolávající se na Palackého a na Tomka. Palacký, má-li editor J. Kalousek na mysli Dějiny národu českého v Čechách a na Moravě, pak k roku 1468 barvitě sepsal tažení Lužičanů a boje u Turnova, o Valečově však zde není ani zmínka (Palacký 1878, 462-465), a stejně je tomu i v odvolávce na Jana z Hubna (SRL I, 91-94). 7 Uvozovky A. Sedláček. 


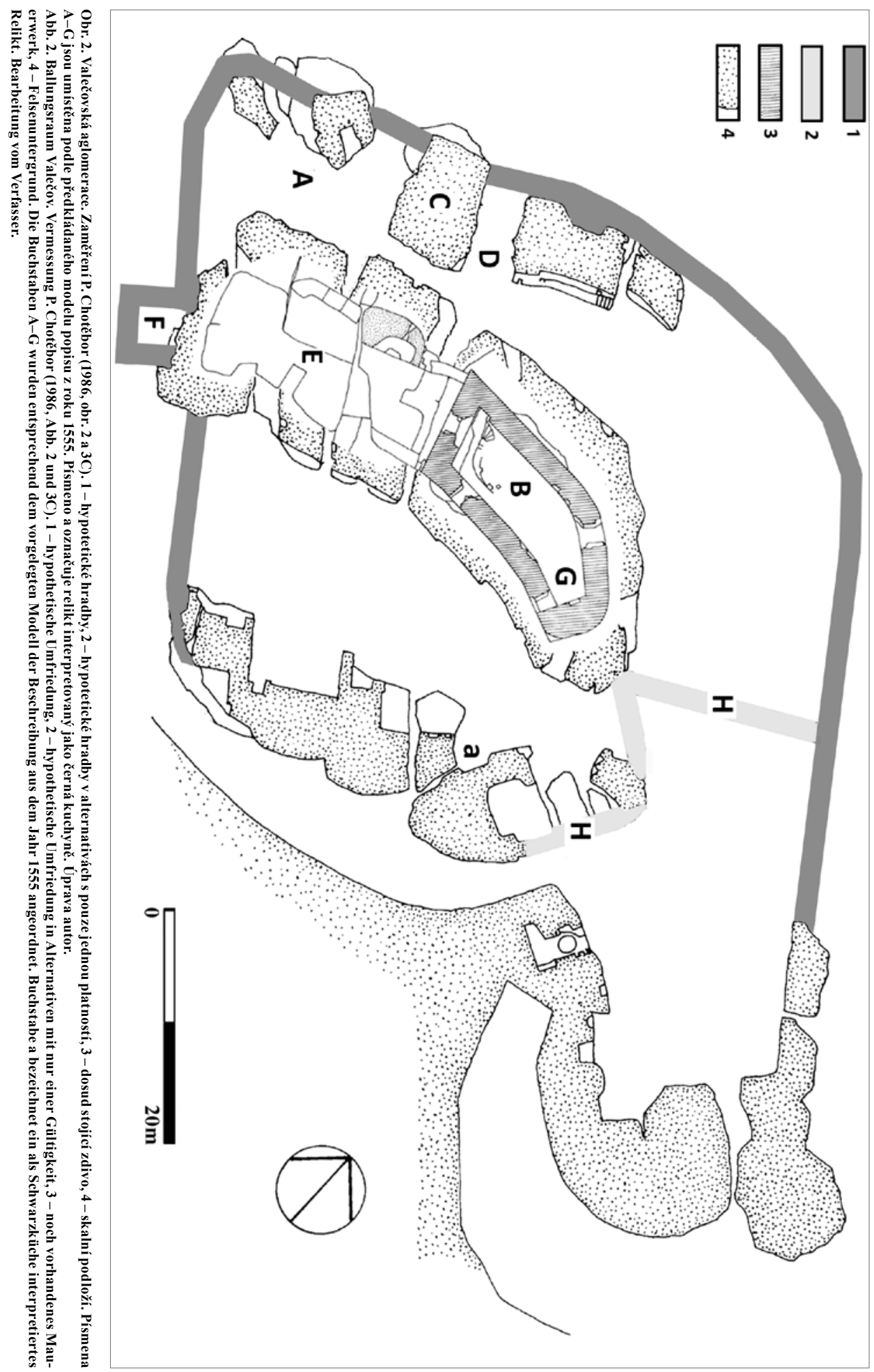


schodě dřevěném chodilo $(\mathrm{C})$, vězení Beneška, marštal klenutá $(\mathrm{L})$ proti fortně $(\mathrm{M})$ is tím, což nad ni bylo, lednice mezi sruby v nově udělaná, ... parkán veliký (N) s fortnou, kudy se do něho vcházelo, ... studnice ve skále ... bránu dolejši ke hradu a na předhradí i s tím domečkem $(\mathrm{O})$ při ní, ve kterémž vrátný bydlel ... předhradí od té brány nahoru až ke kůlně. “8 $\mathrm{Na}$ konci dobového popisu hradu A. Sedláček (1997, 122) uvádí: „Z potomnich příb̌̌hů jde na jevo, že Jindřich díl tento prodal Kryštofovi a že zase měl hrad jednoho pána.“

Je jen velmi obtížné posoudit z popisů, které se nám zdají značně chaotické, správnost výroku A. Sedláčka o sloučení obou dílů Valečova. Z popisů vylučujeme s vysokou mírou pravděpodobnosti dvory, které nepředstavují součást hradu, ale jsou dvory poplužními, samostatnými sídelními jednotkami mimo hrad. Zdá se, že mimo hrad ležela i krčma „Tábor“, kterou popis situuje pod hrad a $\mathrm{v}$ pořadí vypočítávaných částí majetku ji umístil až za dvory a městečko Kněžmost.

Méně jistoty přináší vlastní popisy hradu, dovolující řadu rekonstrukcí sídla. Ze staršího popisu vyplývá, že hradní jádro (hrad, zámek) bylo děleno na přední polovinu (E, obr. 2, 3), do které je započítáno značné množství místností, vysekaných do skalních bloků v domě nad vraty, a na zadní polovinu (B, obr. 2, 3) s pokojem nad předními vraty. K přední polovině popis přiděluje předhradí až ke staré světničce v psinci, která však již náleží k zadní polovině. Podobně je popsáno i dělení mladší, popisující přední část hradu jako starší dům, zadní část hradu potom podrobněji, o to však méně přehledně. Jako velmi pravděpodobné se zdá, že oba zápisy vnímaly hradní jádro (hrad, zámek) pouze jako zástavbu na nejvyšším skalním suku, kde přední polovinu (E, obr. 2, 3) lze spojit se západní, dnes v drobných reliktech dochovanou částí stavby, a východní částí stavby, která se ve zděné podobě dochovala až do výše dvou pater ( $\mathrm{B}$, obr. 2,3$)$. Takto přijímá palácový skalní suk i odborná literatura (Sedláček 1997, 114-115; Chotěbor 1986, 178-182; Durdík 1999, 580).

Ve starším popisu je uváděno dělení předhradí na dvě části podle psince, mladší dělení uvádí malý plac či parkán (A, obr. 2, 3), velký parkán s fortnou $(\mathrm{N}$, obr. 3) a velký plac $(\mathrm{K}$, obr. 3). Lokalizace uvedených ploch nabízí několik alternativ opírajících se především o přehrazení okolí palácového skalního suku hradbami a o jejich prolomení komunikací do hradního jádra, alternativ zůstávajících však v rovině hypotéz. Je až překvapivé, že problémem komunikací se zabýval pouze A. Sedláček $(1997,114)$, který všechny brány uváděné v popisech, s výjimkou jediné, připisuje vstupu zvenku od severovýchodu a západu do předhradí (parkánů). Cesta, kterou autor vede od statku mimo hrad, ke vchodu ze severovýchodní strany, se zdá značně nepravděpodobná. Mnohem pravděpodobnější je komunikace procházející úvozem ve skále z přilehlé sídelní jednotky do prostoru s domnělým vězením Beneškou, ve skutečnosti nejspíše zásobnicí, nebo lednicí. ${ }^{9}$ Prostor asi obíhala zděná hradba, využívající opory skalních výstupů při hraně ostrožny zakomponovaných do zdiva opevnění. Považujeme jej za předhradí, označované $\mathrm{v}$ dobových zápisech jako velký parkán $\mathrm{s}$ fortnou (N, obr. 3). Zde komunikace nabízí dvě varianty. První dovoluje vstup nejkratší cestou přímo na nádvoří, označené jako velký plac (K, obr. 3) a vymezené hradbami mezi konci palácového skalního suku a suku jižního. Procházela by tudy brána, uváděná jako dolejší nebo jako přední vrata (H, obr. 2, 3). Druhá varianta by vedla příchozího kolem hradby nádvoří, kde však nebyla prolomena brána, takže musel dojít až k východnímu konci palácového suku, kde předhradí uzavírala zed', přibližně kolmá k ohrazení nádvoří. V ní prostupovala dolejší brána (přední vrata; H, obr. 2, 3) otevírající parkán, v obou popisech dělený na místě psince. Psinec, shodně s A. Sedláčkem, situujeme k nejužšímu místu parkánu. Z předního, dle př́íchozího ovšem ze zadního parkánu (A, obr. 2, 3) se vstupovalo průrazem prosekaným patou západního bloku palácového suku na nádvoří (velký plac; K, obr. 3). Nádvoří bylo v obou variantách vedení komunikace cílem. Z něho vedl vstup (vstupy) do paláců

8 Uvozovky autor pro text A. Sedláčka. Vynechány podmínky užívání a povinnosti majitelů.

9 Jako zásobnici tento objekt spolu s dalším, vysekaným do podloži samostatné sídelní jednotky ve valečovské aglomeraci, publikovali

F. Gabriel-K. Knop (1990). Možnost využití těchto džbánovitých objektů jako lednic naznačuje zápis z mladšího dělení hradu, kde je uvedena „lednice mezi sruby v nově udělaná“. Zápis by se mohl vztahovat právě k objektu v samostatné sídelní jednotce, kde nelze na počátku 17. stoletî ještě vyloučit zbytky starých srubů. 


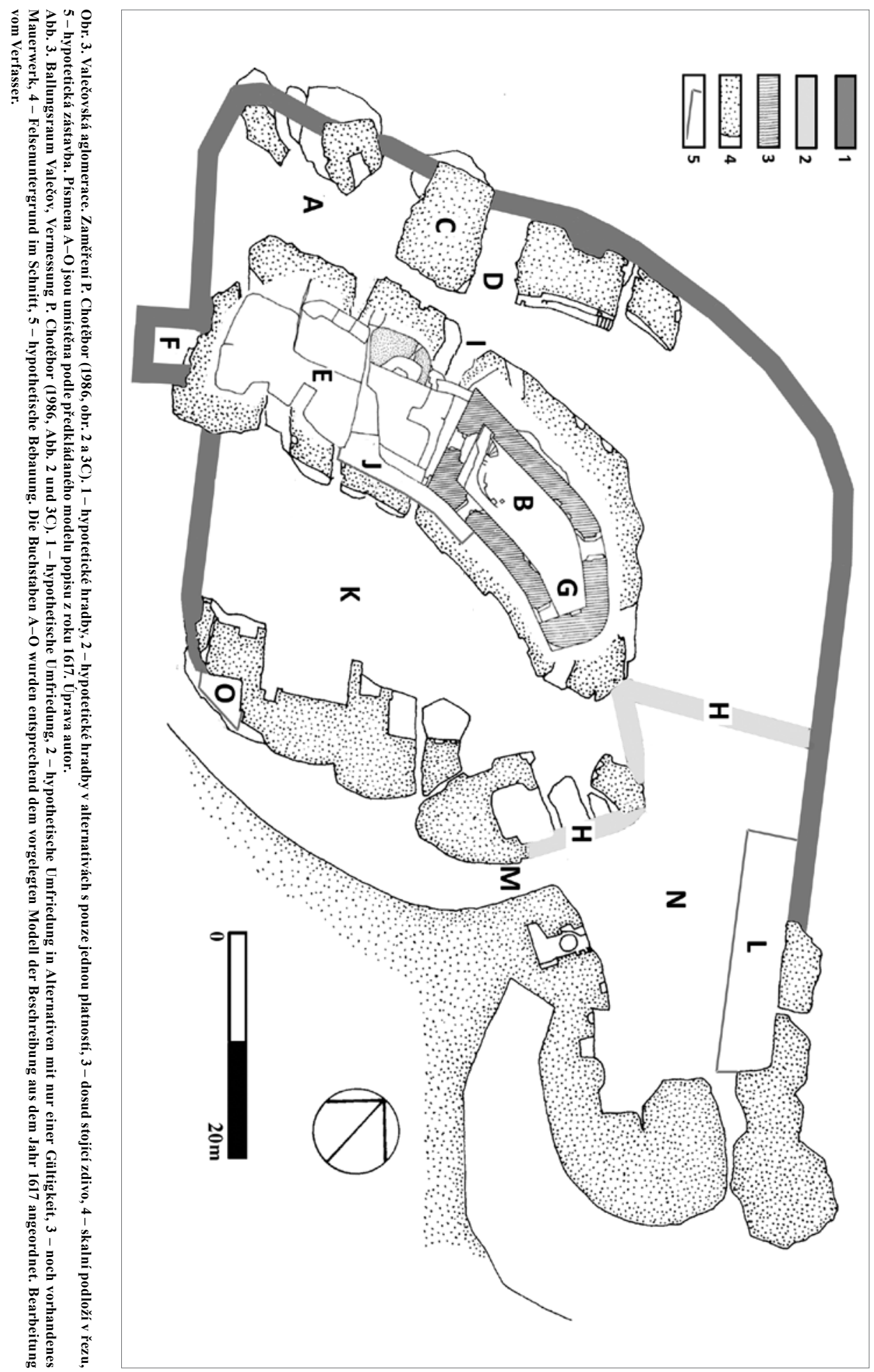


a do objektů přisedajících k jižnímu skalnímu suku. Stály zde pravděpodobně provozní objekty hradu, částečně asi dřevěné, částečně zasekané do skály.

Pokusíme-li se o rekonstrukci vývoje hradu a vzniku aglomerace na základě hodnocení reliktů a stop architektury, zapsaných dobových záznamů a rekognoskace terénu, můžeme vytvořit několik modelů. Článek předkládá pouze jeden, který považuji za nejpravděpodobnější.

Dle tohoto modelu vznikl jako první sídelní jednotka na místě budoucí aglomerace hrad a v době své existence prodělal dvě etapy vývoje. První z nich, známá jen v základních rysech, dala vznik hradu na konci pseudoostrožny. Hrad oddělil šíjový příkop, vysekaný do skalního podloží v místech za příčnou přírodní depresí. Kónicky se rozšiřující prríkop (obr. 7) překonávala cesta, vedoucí přibližně v ose pseudootsrožny, stoupající k mostu, za kterým procházela krátkým úvozem, prosekaným v horní polovině jižního skalního suku, dnes zakrytého z nádvoří střechou domu kastelána (obr. 5). Nejspíše ve stejné výškové úrovni pokračovala i plocha hospodářské části hradu (Gabriel-Smetana 1986, 147), oddělené od hradního jádra výrazným převýšením středního skalního suku, sloužícího snad již tehdy jako staveniště paláce. Jeho podobu neznáme, nelze však vyloučit, že některé stopy a relikty se ukrývají v mladších, dosud zachovaných stavbách. Začlenění třetího, severního skalního suku zůstává, co se týče podoby nejstaršího hradu, rovněž neurčeno.

Nejstarší hrad vznikl asi někdy v první polovině 14. století, rozhodně před rokem 1324 , kdy se jeho jméno uplatnilo v predikátech Bartošů staršího a mladšího. Jeho model představuje první stavební etapu hradu jako samostatné sídelní jednotky. Šlo-li o typ hradu skalního (Gabriel-Smetana 1986), pak náleží k jednomu z nejstarších sídel tohoto dispozičního typu.

Vznik aglomerace, rozšiřující hrad o další dvě sídelní jednotky, jejichž funkci nedovedeme jednoznačně určit, datuji do období husitských válek, kdy pravděpodobně nastala potřeba umístění vojenské techniky a ubytování vojska. Potřebu upravit v okolí hradu vojenskou základnu,

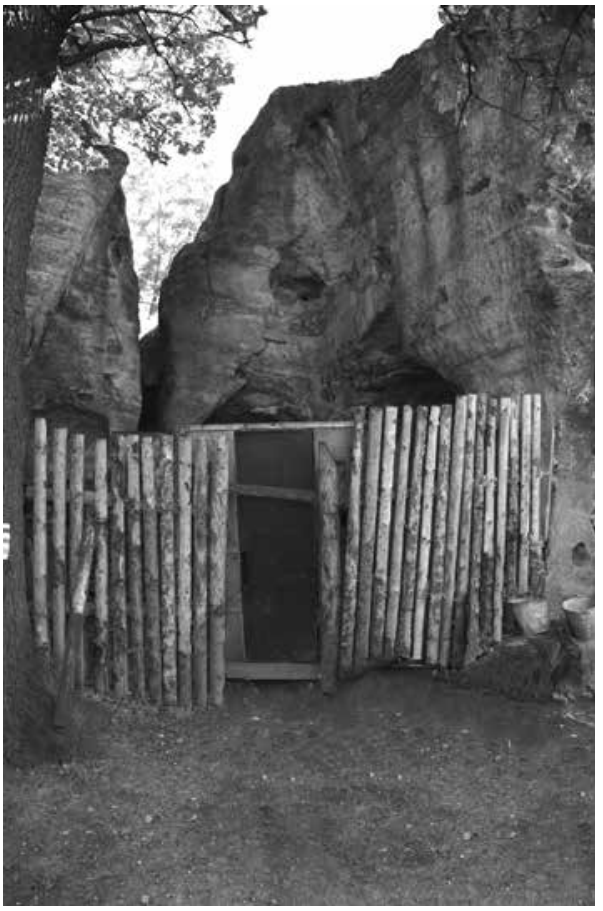

Obr. 4. Valečovská aglomerace. Dýmník černé kuchyně. Foto L. Kursová.

Abb. 4. Ballungsraum Valečov. Rauchabzug der Schwarzküche. Foto L. Kursová. schopnou pojmout vedle vojska i výzbroj a výstroj, zásoby bojovníků, ale především koně a bojové vozy (Smetana-Gabriel 1982, 75), deklarovala odborná literatura již v minulosti (Chotěbor 1986, 178, 187), kladla ji však do prostoru samostatné sídelní jednotky, zatímco přilehlou sídelní jednotku považovala za předhradí. Terén samostatné sídelní jednotky je ovšem členitý a nevhodný pro parkování vozů, které navíc vyžadovaly značný poloměr pro otáčení. $Z$ tohoto důvodu navrhuji přisouzení vojenské základny přilehlé sídelní jednotce na spočinku. Ostatně spočinek pro ležení vojáků využíval asi i hrad Kalich (k. ú. Třebušín, okr. Litoměřice; Smetana-Gabriel 1982) nebo Kunětická hora (k. ú. Ráby, okr. Pardubice).

Valečovský spočinek přisedá přímo k jádru sídelní aglomerace. Současná přístupová cesta jej dělí na severní a západní část. Severní přiléhala k severní obvodové zdi hradu. Jeho stlačený oblouk vymezuje neostrá terénní hrana, která nám nedovoluje rekonstruovat případné opevnění této části sídelní jednotky.

Její druhá část, vymezená ostrou hranou svahu do výrazného oblouku, pokračuje pod hradem v západním směru. Svah v celé délce západní části dělí úzká terasa na horní a spod- 


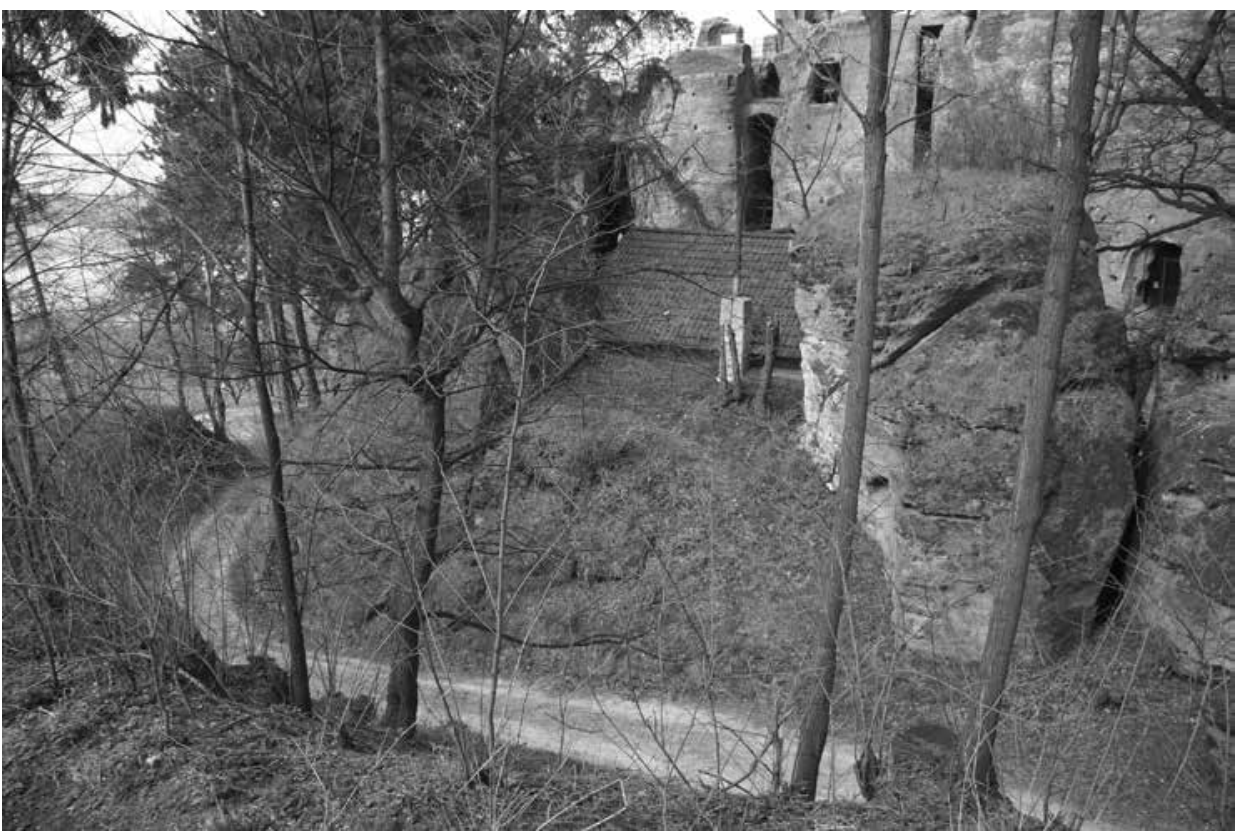

Obr. 5. Valečovská aglomerace. Hypotetický vstup do hradu první stavební etapy, prosekaný v horní polovině jižního skalního suku. Př́íkop sloužil v druhé stavební etapě jako cesta. Foto I. Peřina.

Abb. 5. Ballungsraum Valečov, hypothetischer Eingang zur Burg der ersten Bauetappe, in der oberen Hälfte des südlichen Felssporns durchgehauen. Der Graben diente in der zweiten Bauetappe als Weg. Foto I. Peřina.

ní úsek. Při spodní hraně horního úseku vystupuje na jižní straně spočinku relikt zdiva. Ačkoliv k jeho odkrytí došlo již při zemních pracích v roce 1981 (Chotěbor 1986, 191), dovolil postupný splach zeminy klasifikovat relikty přesněji (Chotěbor 2006, 161-162). Dnes se odkryté zdivo dispozičně zalamuje pod tupými úhly do trojbokého polygonu, jehož 3,3 m dlouhá střední část s úzkým otvorem prostupujícím v jeho ose běží rovnoběžně s hranou terasy. Otvor lemují na vnějším průčelí jizvy po ostěních. Špalety otvoru se rozevírají do dnes nepř́istupného interiéru. Uvedené vlastnosti naznačují, že jde o okenní otvor, plnící nejspíše funkci stř́lny. Zbylé dva úseky zdiva mizí pod svažitým terénem. Stavbu interpretujeme jako polygonální baštu, vystupující před obvodové zdivo spočinku (Gabriel-Peřina-Podroužek 2007). Předpokládáme, že bašta se vázala na hradební zed' obíhající spočinek v místě jeho horní hrany. Za těchto podmínek by hloubka bašty činila přibližně $6 \mathrm{~m}$ a svojí dispozicí by náležela spíše mladšímu horizontu užívání těchto pevnostních prvků, tedy době husitských válek nebo období mladšímu (Durdík 1999, 51-52). Uvedenými relikty se opevnění liší od spočinku pod hradem Kalichem, kde jej naznačuje pouze hrana terénního tvaru, užívaného později jako pole, i od Kunětické hory, kde opevnění spočinku náleží až 16. století (Durdík 1999, 309-311).

Současná přístupová komunikace od severozápadu vyvolává otázku, zda je tato novotvarem, či produktem potřeb vyvolaných středověkou aktivitou, pouze s novověkou úpravou. Jde o jednu z důležitých otázek vstupu na přilehlou sídelní jednotku, at' již její funkce byla jakákoliv. Rekognoskace terénu dovoluje rekonstruovat dva vstupy (obr. 6). Jeden mohl prolomit opevnění nedaleko bašty na jižní straně spočinku. Sloužil by komunikaci od zemědělského dvora na jihozápadě, kde můžeme očekávat jeden z poplužních dvorů a možná i „krčmu pod hradem řečenou Tábor", jmenovanou v roce 1555. S tímto modelem by korespondoval i průběh komunikace ze samostatné sídelní jednotky, sestupující podél předpokládané hradby těsně pod hranu spočinku.

Druhá brána se nabízí na protilehlé straně, v místě, kde komunikace dělí spočinek na dvě části. Otevírala by přístup směřující ke hradu od dnešního parkoviště na severozápadě a stou- 
pající po úpatí opyše. Teoreticky lze na západní část spočinku modelovat tři varianty vstupu (obr. 6). První počítá se dvěma vstupy a předpokládá tedy středověký původ obou cest. Druhá a třetí varianta vpouští do vojenského ležení pouze jeden středověký vstup a k němu př́islušnou vnější komunikaci. Navíc nelze vyloučit užití všech tří variant v různých časových horizontech.

Možnosti př́istupové komunikace rozšiřuje také úzká terasa obíhající celou západní část spočinku (obr. 6). Nevíme totiž, zda šlo o parkán, který svým průběhem kopíroval hlavní hradbu, nebo o úpravu pro komunikaci spojující obě příchozí cesty ještě před vstupem do sídelní jednotky. Konečnou odpověd’ na tuto otázku může dát pouze archeologický výzkum zaměřený na celý komplex otázek souvisejících s opevněním tohoto vojenského ležení.

Vojenské ležení, především př́istup k němu a nepochybně i nutnost propojit jej přímo s hradem, možná i změna postavení majitelů hradu a potřeba jeho kvalitnějšího opevnění v době husitských válek, přinášejících mimo jiné i novou vojenskou techniku, nejspíše vyvolalo potřebu razantní přestavby sídla. Hrad chránila mohutná obvodová hradba. Její stopy registrujeme na jihozápadní straně jižního skalního suku. Směřovala k západnímu konci palácového suku, ke kterému přisedal, jak ukazují stopy na skalní stěně, patrový dům. Spolu s dalším úsekem hradby vymezil obvod hradu na západní straně. V jejím severním závěru a na severní straně hradba výrazně převyšovala drobné skalní bloky, mezi kterými se dosud dochovaly její relikty. Na severní straně zdivo kryje některé bloky skal i po jejich vnější straně jako plenta jejich přisekaných stěn. Za předpokladu, že koruna hradby probíhala $\mathrm{v}$ jedné rovině, kontrastovala, alespoň při pohledu z parkánu, s výškově nestejným založením zdiva. Po skalních blocích stoupají vertikální komunikace, které zpřístupňovaly, alespoň v některých případech, pochozí plochu hradby. Její další průběh na severovýchodním oblouku naznačuje pouze terénní zlom. Závěr hradby na východní straně dokládá v jižním závěru přisekání skály, které rozšířilo hradní areál na jižní straně $\mathrm{k}$ východu, a vytvořilo tak provozní díl hradu, předhradí, zvané v minulosti „velký parkán“ (N, obr. 3). Sem přicházela komunikace z vojenského ležení, která využila starý šíjový příkop, uzavírající v první stavební etapě hrad na jižní straně před jižním skalním sukem. Na něm pravděpodobně kopírovala cestu hradební zed' uzavírající jižní stranu hradu. Nevíme, zda novou přístupovou cestu po dně starého př́íkopu zpř́ístupňovala brána na vstupu z vojenského ležení, nebo až brána na konci úvozu (obr. 7), při vstupu do předhradí, kde ji dokládají stopy vysekané na obou stranách starého příkopu, případně obě brány. Asi pro její ochranu a ochranu jihovýchodní strany předhradí sloužil nově vysekaný př́ikop obíhající obloukem kolem výrazně zvýšeného terénu. Zatímco na severovýchodní straně pseudoostrožny se otevírá do svahu, zakončuje jeho čelo na opačné zúžené straně skála. Zda převýšený terén ještě chránilo další opevnění, nám dnes půdní kryt nedovoluje rozhodnout. Převýšení horní hrany eskarpy oproti horní hraně kontreskarpy však je tak výrazné, že dalšího opevnění nebylo třeba.

Předhradí bylo vybaveno džbánovitým objektem vysekaným do skalního podloží, interpretovaným ve starší literatuře jako vězení Beneška, později jako cisterna, dnes jako zásobnice nebo lednice. Stopy vysekané do skalních stěn a podloží ukazují na další zástavbu, sloužící pravděpodobně pro hospodářské a provozní účely. Podobnou zástavbu můžeme nejspíše očekávat na severní a severovýchodní straně palácového skalního suku. Prostor označovaný v dobových popisech hradu jako parkán se dělí v místech psince, který sem lokalizujeme shodně s A. Sedláčkem $(1997,114)$.

Hradní jádro, př́stupné bud' od severovýchodu z předhradí, nebo od severozápadu z parkánu (A, obr. 2, 3), sestávalo z nádvoří mezi středním a jižním skalním sukem a ze dvou paláců na středním skalním suku. Nádvoří, které někdy v druhé stavební etapě hradu snížilo odlámání skalní ,podlahy“, označuje popis z roku 1617 jako „velký plac“ (K, obr. 3). Rovněž jeho zástavba byla asi do značné míry dřevěná. Zdění si nejspíše vyžádala pouze část černé kuchyně, která přisedala k části vysekané do severní stěny jižního suku (a, obr. 2, 4). Pravděpodobně jde o starší kuchyň, zaniklou ještě před prvním popisem hradu, který již situuje kuchyň do starého paláce. K západní stěně středního suku, zvoleného pro stavbu paláce, přisedala nejspíše zděná věžovitá budova, popisem z roku 1555 snad označovaná za věž (F, obr. 2, 3). Vlastní suk proložil palác řadou vysekaných místností, zatímco jeho horní plató posloužilo jako staveniště horních 


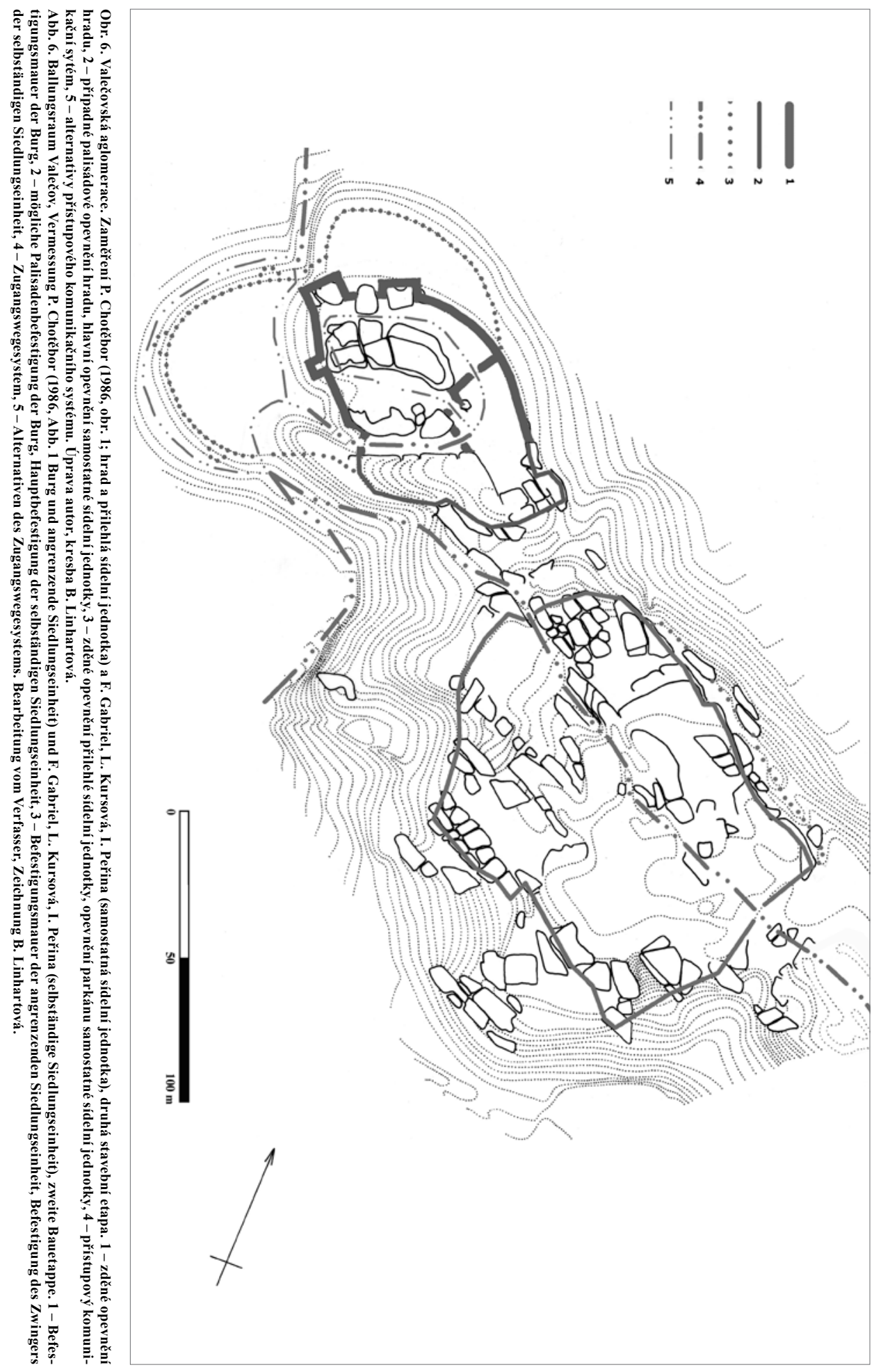




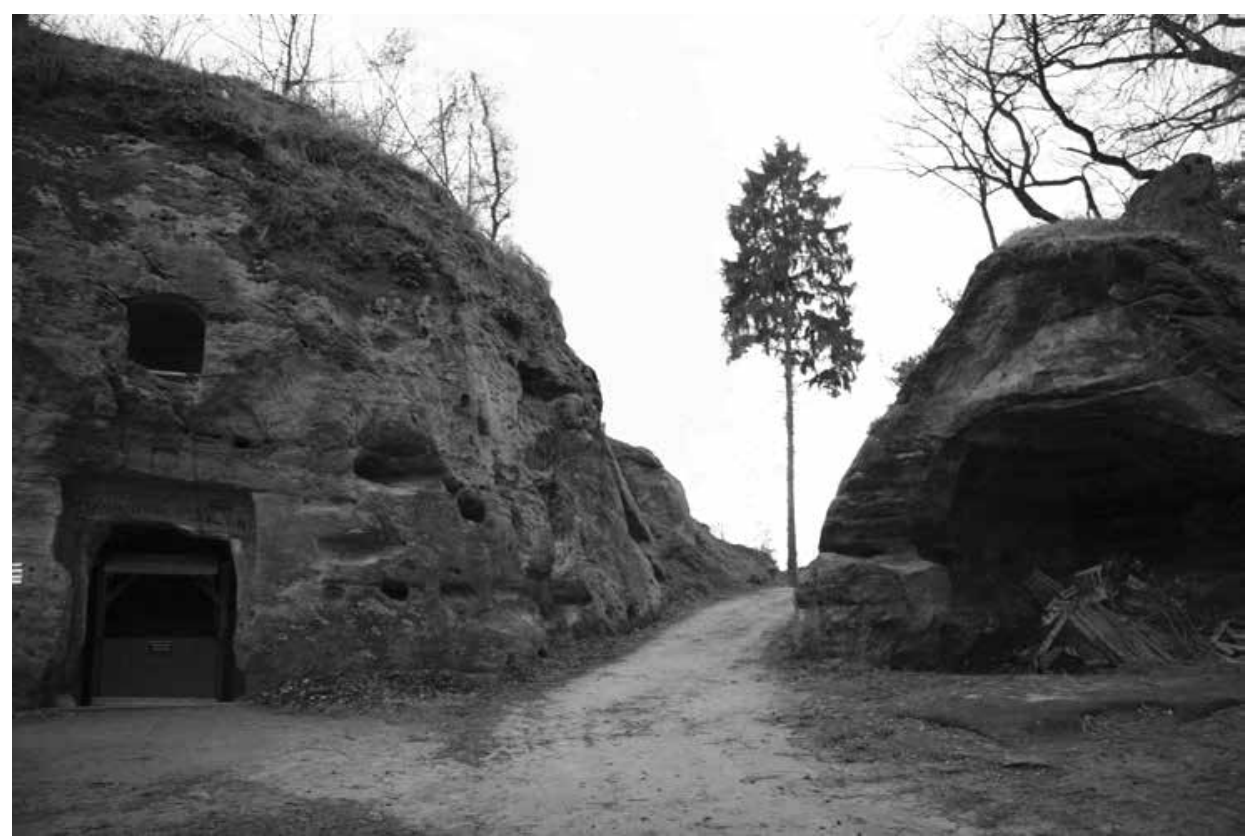

Obr. 7. Valečovská aglomerace. Vstup do předhradí zleva se zásobnicí, se stopami fortny v úvozu a s reliktem př́izemního objektu. Foto L. Kursová.

Abb. 7. Ballungsraum Valečov. Eingang zur Vorburg von links mit Vorratsspeicher und Spuren des Burgtors mit dem Relikt eines ebenerdigen Objektes. Foto L. Kursová.

partií paláce, v nejstarší formě asi pouze dřevěných, nejspíše roubených či hrázděných. Jejich vývoj nepochybně pokračoval nejvýraznějšími stavebními změnami, které dnes ve druhé stavební etapě dělíme do tři fází. První fáze, snad navazující na palác první etapy, přizpůsobovala skalní podloží stavbě sekáním, jak to vidíme na západní straně palácového suku. Č́sti stavby vysekané do skály doplňoval stavebník roubením či bedněním, př́padně dřevěnou konstrukci vyplnil hlínou. Zda takto budovaný palác zabíral pouze západní stranu horního plató suku, nebo horní plató celé, dnes asi již nezjistíme, nebot' východní polovinu překryl někdy v období mezi druhou čtvrtinou 15. století a první polovinou století šestnáctého, v době druhé fáze, nový palác (B, obr. 2, 3). Jako nejpravděpodobnější stavebník se jeví Vaněk z Valečova a na Kněžmostě, nepochybně zámožný královský podkomoří (Šimák 1917, 268-269), nebo jeho nástupce ve funkci, švagr a dědic, Samuel z Hrádku a z Valečova (Kolektiv autorů 1984, 493). Druhé polovině 15. století odpovídá i struktura jeho zdiva, nečetné dosud existující články a úpravy dispozice, jakou naznačují jeho dochované relikty. ${ }^{10}$ Teprve později, spíše až někdy po roce 1617, proběhla fáze třetí, kladená v odborné literatuře většinou již do 16. století (Menclová 1972, 341; Kolektiv autorů 1984, 493-494; Chotěbor 1986, 182). Jejím výsledkem bylo nadezdění nového paláce o druhé patro, které mělo nahradit patro či polopatro starší, dřevěné. Otázkou zůstává, zda dřevěná nástavba na obytném patře stála. Popis hradu z roku 1617 uvádí nad obytným prvním patrem krov. To je také důvodem datace její výstavby do doby po roce 1617, kterou naznačuje i hojné uplatnění cihel ve výrazně zeslabeném zdivu a především v segmentových klenbách okenních záklenků. Detailní vyhodnocení paláců, především jejich vývoje a vzájemného vztahu řešil P. Chotěbor (1986, 178-182), bohužel však bez přístupu k vyšším partiím zdiva. To zpřístupnila v minulých letech jejich konzervace a nezbývá, než čekat na informace o případném novém vyhodnocení.

10 Při hodnocení dispozice a reliktů zdiva bylo využito poznatků z cesty do Francie realizované v rámci grantu Corona Culturae reg. č. CZ.1.07/2.2.00/28.0285. 
Samostatná sídelní jednotka vznikla bez př́imého komunikačního spojení s hradem (obr. 6). Její „urbanistické“ rozložení již respektuje změnu hlavní komunikace i opevnění vstupní brány předhradí novým prŕíkopem. Třetí sídelní jednotka tak naznačuje dobu svého vzniku až po základním dispozičním rozvrhu druhé stavební etapy hradu a rozšíření aglomerace o vojenskou základnu. Na rozdíl od ní se však na opevnění hradu neváže a, jak naznačuje terénní rekognoskace, je zabezpečena vlastními obrannými prvky v celém rozsahu. Na jihovýchodní straně přetíná pseodoostrožnu šíjový př́íkop, stoupající k jejímu hřebeni, kde odkryté skalní podloží nese stopy sekání několika skalních bloků plnících funkci mostního pilíre, eskarpy a kontreskarpy. V nižších partiích naznačují lavice na dně příkopu vytěžení lámáním.

Hlavní opevnění zajištovaly svislé stěny skal, doplněné v místech širších puklin či zřícených skalních bloků tarasením dřevěnými konstrukcemi, doplněnými nejspíše hlínou a kamením. Na horní hraně takto upravené podnože sídla mohlo obránce chránit opevnění, které však není při pouhém ohledání terénu patrné. Dvě zjištěné formy tarasení a s nimi spojené otázky uvádějí F. Gabriel-I. Peřina-K. Podroužek (v tisku). Hlavní liniové opevnění doplňuje po celé severovýchodní straně parkán, projevující se zarovnáním terénu u paty skal pseudoostrožny a valem či spíše rozvalenou parkánovou zdí na hraně zarovnání (obr. 6). Val přerušují na několika místech skalní bloky. Zatímco na straně severovýchodní parkán jednoznačně končí a v šíjovém př́ikopu jej nenacházíme, na protilehlé severní straně jeho pokračování nebo ukončení jednoznačně patrné není. Na západním konci severního úseku opevnění prostupovala brána, za kterou dál přesný průběh opevnění ztrácíme a odhadujeme jej pouze podle půdní hrany terénu na severozápadní straně sídla. Teprve na západní straně se vrací na koncích skalních suků stopy dřevěných tarasů. Stěny bloků jihozápadního suku ukončují sídlo až ke spodnímu konci šíjového př́kopu.

Př́istup do sídelní aglomerace přicházel ve středověku po jihovýchodní ose na vrcholu pseudoostrožny. Místy nevýrazné relikty opevnění, lemující př́stupovou komunikaci před příkopem, nevylučují uplatnění barbakánu chránícího most. Cesta překonala šíjový příkop po mostě, za skalním pilířem nejspíše padacím, a pokračovala přerušovaným mělkým úvozem k druhé bráně na západním konci severního úseku opevnění, kde sídlo opustila (obr. 6). Její další průběh terénní relikty nedokladují, nejspíše však klesala mimo opevnění k západu, kde vyústila na cestu od dvora $\mathrm{k}$ vojenské základně. Tuto páteřní komunikaci nepochybně doplňovala uvnitř sídla řada dalších cest (ulic), které ovšem v terénu jednoznačně určit nedovedeme.

Ulice procházely mezi jednotlivými domy, jejichž spodní podlaží vysekané do podloží se dosud dochovalo v počtu 89 objektů. Zástavbu datují podle formálních znaků K. PodroužekF. Gabriel (2007) do tří časových horizontů. První z nich s 23 objekty autoři spojují ,s tzv. menšim Táborem orebitských husitských vojsk Bernarda a Bartoše Valečovských“. Terénní situace zde sice není vhodná k umístění vozů a těžších zbraní polního vojska, dovolovala však v bezprostřední blízkosti vyhovujícího místa ubytovat vojáky, jejich rodiny a řemeslníky zajišt'ující servis takovéto komunitě. Samostatná sídelní jednotka vznikla asi nedlouho před rokem 1423 a zanikla v roce 1439, kdy narativní pramen (StL, 137) uvádí úplné vypálení Valečova (Podroužek-Gabriel 2007, 213). Vyloučit dle našeho názoru nelze ani rok 1470, kdy došlo k vypálení městečka pod Valečovem (AČ VIII, 3-4 č. 379).

Druhou sídelní aktivitu, které dle K. Podroužka-F. Gabriela (2007, 215-222) náleží 36 objektů, kladou autoři do období exodu Jednoty bratrské z Mladé Boleslavi, tedy mezi roky 1469 až $1621 \mathrm{~s}$ tím, že provizorní bydlení mohlo přerůstat do trvalého osídlení. Některé objekty překročily opevnění města a spolu s rybníkem, jehož stopy leží západně pod městečkem, rozšíriily rozlohu sídla.

Třetí horizont s 26 objekty spojují výše uvedení autoři (2007, 213-215) s osídlením 19. století, úředně vyklizeným 5. 10. 1892, s možným přesahem až do počátku 20. století.

Valečovská sídelní aglomerace nabízí odborníkům množství cenných informací o architektuře z období 14.-19. století, dobře čitelných v objektech a stopách po nich, vysekaných do pískovcového podloží. Současně však představuje ojedinělou a mimořádně cennou ukázku byd- 
lení člověka ve středověku a novověku. O to překvapivější je nezájem státu o tento ojedinělý pramen, podléhající bez ochrany a pravidelné konzervace pozvolnému, ale trvalému poškozování.

Článek je součástí projektu katedry archeologie Filozofické fakulty Západočeské univerzity v Plzni, probíhajícího v rámci grantu SGS-2014-041.

\section{Prameny a literatura}

AČ: Archiv český I (Palacký, F., ed.). Praha 1840; IV (Palacký, F., ed.). Praha 1846; VIII (Kalousek, J., ed.). Praha 1888; XV (Kalousek, J., ed.). Praha 1896.

DURDÍK, T., 1999: Ilustrovaná encyklopedie českých hradů. Praha.

FILIP, J., 1947: Dějinné počátky Českého ráje - The historic beginnings of the Bohemian Paradise. Praha.

GABRIEL, F.-KNOP, K., 1990: K interpretaci džbánovitých objektů na pískovci - Zur Interpretation krugartiger Objekte im Sandstein, AH 15, 261-274.

GABRIEL, F.-PANÁČEK, J.-PODROUŽEK, K., 2011: Helfenburk hrad pražských arcibiskupů - Helfenburk Burg der prager Erzbischöfe. Dř́ísy.

GABRIEL, F.-PEŘINA, I., 2009: Problémy vývoje keramiky ve středním Pojizeří - Probleme der Keramikentwicklung in der mittleren Isergegent, AH 34, 71-83.

GABRIEL, F.-PEŘINA, I.-PODROUŽEK, K., 2007: Nový doklad opevnění valečovské sídelní aglomerace, ČSPS $115,110-112$.

- v tisku: Die Befestigung der Siedlungsballung Valečov, CaBe 10.

GABRIEL, F.-SMETANA, J., 1986: Skalní hrady a jejich vztah k české hradní architektuře - Felsenburgen und ihre Beziehung zur böhmischen Burgarchitektur, AH 11, 143-152.

CHOTĚBOR, P., 1986: Komplexní povrchový průzkum hradu Valečova - Komplexe oberflächenerforschung der Burg Valečov, PA LXXVII, 177-196.

- 2006: Hynšta und Valečov, zwei unterschiedliche Beispiele von "Felsenburgen" in Sandsteinmassiv unter dem Berg Mužský - Hynšta and Valečov, Two Different Examples of "Rock Castles" in the Sandstone Massif of Mužský, CaBe 9, 157-166.

KLÁPŠTĚ, J., 2013: Počátky Markvarticů a jejich sídelní souvislosti v Pojizeří - The beginnings of the Markvartici kin-group and their settlement contexts in the Jizera River region, AR LXV, 321-372.

KOLEKTIV AUTORŮ, 1984: Hrady, zámky a tvrze v Čechách, na Moravě a ve Slezsku (III). Severní Čechy (Anděl, R., ed.). Praha.

LC: Libri confirmatium ad beneficia ecclesiastica Pragensem per archidioecesim: I/1 (Tingl, F. A., ed.). Praha 1867; VII (Emler, J., ed.). Pragae 1886.

LE: Libri erectionum archidioecesis Pragensis saeculo XIV. et XV.: IV (Borový, C., ed.). Pragae 1883.

MENCLOVÁ, D., 1972: České hrady, díl druhý. Praha.

PALACKÝ, F., 1878: Dějiny národu českého v Čechách a na Moravě IV/II. Praha.

PODROUŽEK, K.-GABRIEL, F., 2007: Typy objektů valečovského „městečka“ - Objekttypen des Valečover „Städtchens“, AH 32, 211-224.

RTT: Reliquiae tabulárum terrae regni Bohemiae: I (Emler, J., ed.). Praha 1870; II (Emler, J., ed.). Pragae 1872.

RTV: Reliquiae tabulárum terrae citationum vetustissimae (Dvorský, F.-Emler, J., edd.). Praha 1868.

SEDLÁČEK, A., 1994: Hrady, zámky a tvrze království českého II. Praha.

- 1997: Hrady, zámky a tvrze království českého X. Praha.

SMETANA, J.-GABRIEL, F., 1982: K otázce datování, typu a funkce hradu Kalicha u Litoměřic - Zu den Fragen der Datierung, des Typs und der Funktion der Burg Kalich bei Litoměřice, FHB 4, 49-82.

SRL: Scriptores rerum Lusaticarum: I. Goerlitz 1839.

StL: Ze starých letopisů českých (Porák, J.-Kašpar, J., edd.). Praha 1980.

ŠIMÁK, J. V., 1917: Dějinné paměti okresu mnichovohradišt'ského I. Mnichovo Hradiště.

- 1930: Soupis památek historických a uměleckých v okresu mnichovohradištském. Praha.

WALDHAUSER, J.-SOSNOVEC, P., 2004: Nová archeologická zjištění o hradech Pojizeří - Neue Erkenntnisse der Burgen im Flussgebiet der Iser, CB 9, 383-386. 


\section{Zusammenfassung}

\section{Entwicklungsmodell der Siedlungsballung Valečov}

Die Siedlungsballung Valečov entstand auf einem langgestreckten Pseudobergsporn aus Sandstein, dessen Achse vom Spornhals zur Spornspitze von Südosten nach Nordwesten verläuft. Aus dem Boden ragen präparierte Sandsteinblöcke, die an der Spornspitze in bis zu $30 \mathrm{~m}$ hohen und quer zur Achse des Pseudobergsporns stehenden Felsspornen angeordnet sind. Die Siedlung erstreckt sich über eine Fläche von ca. $59009 \mathrm{~m}^{2}$. Sie besteht aus der eigentlichen Burg mit Kern- und Vorburg mit einer Ausdehnung von ca. $3815 \mathrm{~m}^{2}$, aus einer Siedlungseinheit mit der Fläche von ca. $12992 \mathrm{~m}^{2}$ mit einer Befestigung, die an die höher gelegene Burg anschließt, und aus einer südöstlich von der Burg gelegenen Siedlungseinheit mit der Fläche von $42202 \mathrm{~m}^{2}$ mit eigener abgeschlossener Befestigung. Die Fundstelle Valečov stellt uns vor eine Reihe von Fragen, die mit Entstehungszeit, Besitzverhältnissen, Veränderungen der Siedlungsballung und den jeweiligen Funktionen der Siedlungseinheiten zusammenhängen. Über die Existenz der Burg werden wir erstmals durch das Adelsprädikat „Bartoss iuuenis de waleczowa et de strak“ aus dem Jahr 1323 unterrichtet. Der überwiegende Teil der Funde datiert sie an das Ende des 14. Jahrhunderts und in den anschließenden Zeitraum. Scheinbar wird eine ältere Gründung der Burg nicht eindeutig durch die ältesten Keramikfragmente von Gefäßen aus dem 13. Jahrhundert belegt. Aufgabe und Untergang der Burg stellten sich laut verschiedenen Forschern irgendwann zwischen 1622 und der ersten Hälfte des 18. Jahrhunderts ein. Deutlich weniger Informationen sind über Funktion und Stellung der einzelnen Siedlungseinheiten erhalten geblieben. Gewiss ist lediglich die Burg selbst, obwohl auch bei ihr eine Reihe von Fragen ungeklärt bleiben. Als Ausgangspunkt für die Modellierung der Funktion, Stellung und Eingriffe in das Aussehen der Siedlungsballung Valečov wählen wir erhalten gebliebene zeitgenössische Aufzeichnungen, welche die einzelnen Siedlungseinheiten spezifizieren. Die ersten Informationen über die kompliziertere Siedlungssituation von Valečov liefert die Adresse auf einer Urkunde „An Bartoš, Bernart aus dem kleineren Lager von Valečov". Weitere Informationen nennen das Jahr 1439, als die eroberte Burg ,vollständig niederbrannte“. Im Jahr 1470 wurde die Minderstadt unterhalb von Valečov niedergebrannt. Aus den Jahren 1555 und 1617 kommt es in Aufzeichnungen über die Aufteilung der Gutsherrschaft zu Beschreibungen der Burg. Bei dem Versuch, ihre Entwicklung aufgrund einer Auswertung der Relikte und architektonischen Spuren, niedergeschriebenen Aufzeichnungen und Terrainrekognoszierung können wir mehrere Modelle entwerfen. Im vorliegenden Beitrag wird lediglich das Modell vorgestellt, das dem Verfasser als das wahrscheinlichste erscheint. Laut ihm entstand die Burg als erste Siedlungseinheit der Ballung und hat während ihrer Existenz zwei Entwicklungsetappen durchgemacht. Die erste von ihnen kennen wir nur in ihren Grundzügen. Die zweite Bauetappe begann am Anfang der Hussitenkriege und hängt mit einer Erweiterung der Siedlungsballung um zwei neue Siedlungseinheiten und mit der Verlegung des Zugangswegs zur Burg zusammen. Ihre Funktionen vermögen wir nicht eindeutig zu bestimmen, jedoch bringen wir sie mit der Konzentration und dem Schutz der Bevölkerung während den Unruhen in Verbindung. Die angrenzende Siedlungseinheit diente als Militärlager, das auch Pferde und Streitwagen aufnehmen kann. Einer ähnlichen Siedlungseinheit begegnen wir auch auf Burg Kalich (Katastergebiet Třebušín, Bez. Litoměřice) oder auf Burg Kunětická hora (Katastergebiet Ráby, Bez. Pardubice). Die selbständige Siedlungseinheit respektiert bereits den geänderten Zugangsweg zur Burg sowie den Aufbau der angrenzenden Siedlungseinheit. Die Siedlungsballung Valečov liefert für Fachleute eine Fülle an wertvollen Informationen über die Architektur aus der Zeit des 14.-19. Jahrhundert, die an den gemauerten Relikten, vor allem aber an den in den Sandsteinuntergrund gehauenen Objekten und ihren Spuren gut ablesbar sind. Gleichzeitig stellt sie jedoch ein einzigartiges und außerordentlich wertvolles Vorzeigestück dessen dar, wie der Mensch im Mittelalter und in der Neuzeit gewohnt hat. Um so überraschender ist dann das Desinteresse des Staates an dieser einzigartigen Quelle, 
die ohne Schutz und regelmäßige Konservierung einem allmählichen und nachhaltigen Zerfall anheimfällt.

Der vorliegende Beitrag ist Bestandteil des Studentenförderprojektes SGS-2014-041 des Lehrstuhls für Archäologie der Philosophischen Fakultät der Westböhmischen Universität in Pilsen.

Doc. PhDr. František Gabriel, Ph.D., Katedra archeologie Filozofické fakulty Západočeské univerzity v Plzni, Sedláčkova 15, 30614 Plzeň, pu-uvpd-cl@volny.cz 
